\title{
Наши поздравления!
}

Михаилу Александровичу Маслину - 70!

\section{ЕДИНСТВО В МНОГООБРАЗИИ, ИЛИ РАЗНОЛИКОСТЬ ПРОФЕССОРА М.А. МАСЛИНА (В связи с выходом книги: Маслин М.А. Разноликость и единство русской философии. - СПб.: Издательство РХГА, 2017. - 526 с.)}

\section{B.A. ГУТОРОВ}

Санкт-Петербургский государственный университет, Санкт-Петербург, Россия

А.А. ШИРИНЯНЦ

Московский государственный университет имени М.В. Ломоносова, Москва, Россия

\section{Аннотация}

В статье анализируются многообразные аспекты творческого вклада проф. М.А. Маслина в исследование фундаментальных проблем истории русской философии. Важным итогом его научной деятельности является книга «Разноликость и единство русской философии» (2017), в которой представлены оригинальные авторские подходы к разработке сложных проблем историографии русской философской традиции XVIII-XXI вв. История жизни и творчества русских мыслителей разных эпох и направлений образует, по мысли автора, сложный полифонический диалог идей единого круга «лиц», определивших в эпоху модерна магистральные направления русской мысли. Особое внимание уделяется в статье глубокому анализу проф. М.А. Маслиным основных направлений эволюции русской либеральной философии и политической мысли, политических и социологических аспектов творчества М.М. Бахтина, а также весьма специфических проблем, связанных с различными этапами формирования антропологических, философских и социально-политических концепций русского евразийства и его предшественников (например, «протоевразийство» В.И. Ламанского и К.Н. Леонтьева). Подчеркивается также созвучность новаторских научных разработок М.А. Маслина теоретическим поис- 
кам крупнейших представителей зарубежных школ анализа русской философской традиции (А. Валицкий), а также различных направлений западной культурологии (Э. Ауэрбах) и политической теории (Ч. Мэрриам).

Ключевые слова: профессор М.А. Маслин, русская философия, историография, либерализм, русское евразийство, либеральная традиция, культурология, социологический анализ.

Гуторов Владимир Александрович - доктор философских наук, профессор, заведующий кафедрой теории и философии политики факультета политологии Санкт-Петербургского государственного университета.

gut-50@mail.ru

Ширинянц Александр Андреевич - доктор политических наук, профессор, заведующий кафедрой истории социально-политических учений факультета политологии Московского государственного университета имени М.В. Ломоносова.

jants@yandex.ru

Цитирование: ГУТОРОВ В.А., ШИРИНЯНЦ А.А. (2018) Единство в многообразии, или Разноликость профессора М.А. Маслина (В связи с выходом книги: Маслин М.А. Разноликость и единство русской философии. - СПб.: Издательство РХГА, 2017. - 526 с.) // Философские науки. 2018. № 2. С. 107-119. DOI: 10.30727/0235-1188-2018-2-107-119.

В далеком 1988 г. редколлегия журнала «Философские науки» обратилась к молодому кандидату наук, только что защитившему диссертацию «по идеологам русского революционного народничества», с предложением написать рецензию на книгу старшего научного сотрудника философского факультета Московского университета имени М.В. Ломоносова - Михаила Александровича Маслина, только что защитившего докторскую диссертацию «Современные буржуазные концепции истории русской философии (от Радищева до революционных народников)». Рецензия на книгу [Ширинянц, Милохина 1989, 126-127] была опубликована в ФН-3 за 1989 г.

Спустя много лет появился приятный повод откликнуться на очередную книгу нашего друга и учителя. Выход этой довольно объемной книги «Разноликость и единство русской философии», изданной стараниями РХГА [Маслин 2017], приурочен к юбилею М.А. Маслина (р. 1947) и приближающейся 75-й годовщине со дня основания в МГУ кафедры истории русской философии 
теллигенции. Такой методологический подход к исследованию политической культуры русской интеллигенции, игравшей рационально-активистскую «роль» в истории России, дает возможность показать всю сложность этого феномена [Ширинянц $2011,57]$. И, в конечном счете, признать, что предназначение русской интеллигенции - не «провокативные» (любимое слово М.А. Маслина) заявления и действия политического характера, не продажа чего-либо, включая «образовательные услуги», не бюрократическое функционирование, а формирование и сохранение духовных, культурных ценностей - то, что М.А. Маслин называет очень точным термином «хранительство» [Минаков, Перевезенцев, Ширинянц (ред.) 2016, 17].

Одним из таких «хранителей» и является сам профессор М.А. Маслин - русский интеллигент, патриот России, ученыйфилософ, обладающий большой эрудицией, бережно хранящий в своих трудах «разноликость и единство» русской философии.

\section{ЦИТИРУЕМАЯ ЛИТЕРАТУРА}

Анархизм 2016 - Анархизм: pro et contra, Социально-политическое явление глазами его российских сторонников, критиков и отечественных ученых-исследователей. Антология. - СПб.: Издательство РХГА, 2016.

Ауэрбах 1976 - Ауэрбах Э. Мимесис. Изображение действительности в западноевропейской литературе. - М.: Прогресс, 1976.

Бахтин 2000 - Бахтин М. Автор и герой. К философским основам гуманитарных наук. - СПб.: Азбука, 2000.

Борисов, Гончаров (сост.) 2017 - Социализм: pro et contra, антология / сост. И.В. Борисова и И.А. Гончарова. - СПб.: Издательство РХГА, 2017.

Волошинов 1926 - Волошинов В.Н. Слово в жизни и слово в поэзии. К вопросам социологической поэтики // Звезда. 1926. № 6. С. 244-267.

Волошинов 1993 - Волошинов В.Н. (М.М. Бахтин) Марксизм и философия языка: Основные проблемы социологического метода в науке об языке. - М.: Лабиринт, 1993.

Гуторов (сост.) 2015 - Ф. Рузвельт: pro et contra. Антология. Образы союзников-победителей в культурной памяти о Войне 1941-1945 гг. / сост. В.А. Гуторова - СПб.: Издательство РХГА, 2015.

Гуторов (сост.) 2017 - В.И. Ленин: pro et contra, антология / Сост. вступ. ст., коммент. В.А. Гуторова. - СПб.: Издательство РХГА, 2017.

Гуторов, Светлов (сост.) 2016 - Либерализм: pro et contra. Антология / сост. В.А. Гуторова, Р.В. Светлова. - СПб.: Издательство РХГА, 2016.

Данилевский, Роговер, Стадников (сост.) 2015 - И.В. Гёте: pro et contra, антология. 2-е изд., испр. / сост. Р.Ю. Данилевского, Е.С. Роговера, Г.В. Стадникова. - СПб.: Издательство РХГА, 2015. 


\section{В.А. ГУТОРОВ, А.А. ШИРИНЯНЦ. Единство в многообразии, или Разноликость...}

Маслин (ред.) 2007 - Энциклопедия / под общ. ред. М.А. Маслина. М.: Алгоритм, 2007.

Маслин 2013 - Маслин М.А. Евразийство как идейное течение: Истоки и границы // Лев Николаевич Гумилев и современное евразийство (Lev Nikolayevich Gumilev and Contemporary Eurasianism): сборник статей, посвященных 100-летию ученого / под ред. А.Г. Коваленко, В.А. Цвыка. М.: РУДН, 2013. С. 11-25.

Маслин (ред.) 2014 - Энциклопедия / под общ. ред. М.А. Маслина. М.: Алгоритм, 2007.

Маслин 2017 - Маслин М.А. Разноликость и единство русской философии. - СПб.: Издательство РХГА, 2017.

Минаков, Перевезенцев, Ширинянц (ред.) 2016 - Хранители России. Антология. Т. 3. Рождение русского консерватизма. 1800-1850 гг. / под ред. А.Ю. Минакова, С.В. Перевезенцева, А.А. Ширинянца. - М.: Паблис, 2016.

Назарбаев 1997 - Назарбаев Н. Евразийский Союз: идеи, проблемы, перспективы. Доклад на встрече с общественностью. Москва, 22 октября 1994 г. // Назарбаев Н.А. Евразийский Союз: идеи, практика, перспективы. 1994-1997. - М., 1997.

Иванова, Казина, Котова и др. (сост.) 2017 - Национализм: pro et contra, антология / сост. А.А. Иванова, А.Л. Казина, А.Э. Котова и др. СПб.: РХГА, 2017.

Перевезенцев 2016 - Перевезенцеев C.B. К вопросу о национальном характере русской социально-политической мысли XVIII века // Вестник Российской нации. 2016. Т. 49. № 3-4. С. 167-178.

Русская философия 2014 - Русская философия. Энциклопедия. 2-е изд., дораб. и доп. / под общ. ред. М.А. Маслина. - М.: Книжный Клуб «КниговеК», 2014.

Ширинянц 2002 - Ширинянц А.А. Вне власти и народа. Политическая культура интеллигенции России ХІХ - начала XX века. - М.: РОССПЭН, 2002.

Ширинянц 2011 - Шириняни А.А. Нигилизм или консерватизм? (Русская интеллигенция в истории политики и мысли). - М.: Изд-во Моск. ун-та, 2011.

Ширинянц, Милохина 1989 - Ширинянц А.А., Милохина М.М. М.А. Маслин. Современные буржуазные концепции истории русской философии. Критический анализ. - М., 1988 // Философские науки. 1989. № 3. С. 126-127.

Шутов, Ширинянц (ред.) 2015 - Шутов А.Ю., Шириняни А.А., Сорокопудова О.Е., Мырикова А.В., Сетов Н.Р., Топьчканов А.В., Осадченко 3.Н. Россия в западном зеркале: отражения и искажения. Русский вопрос в истории политики и мысли. Антология / под ред. А.Ю. Шутова, А.А. Ширинянца // Тетради по консерватизму. Альманах Фонда ИСЭПИ. 2015. № 2. С. 175-207. 
Merriam 1964 - Merriam Ch.E. Political Power. With a New Introduction of H.D. Lasswell. - New York: Collier Books, 1964.

Walicki 2015 - Walicki A. The Flow of Ideas. Russian Thought from the Enlightenment to the Religious-Philosophical Renaissance. - Frankfurt am Mein: Peter Lang, 2015.

\title{
THE UNITY IN DIVERSITY OR THE VERSICOLOURED FACES OF PROFESSOR M.A. MASLIN (In Connection with the Publication of the Book: Maslin M.A. Diversity and the Unity of Russian Philosophy. - Saint Petersburg, \\ Russian Christian Humanities Academy Publ., 2017. - 526 pp.)
}

\author{
V.A. GUTOROV \\ Saint Petersburg State University, \\ Saint Petersburg, Russia \\ A.A. SHIRINYANTS \\ Lomonosov Moscow State University, \\ Moscow, Russia
}

\section{Summary}

The article analyzes the diverse aspects of the creative contribution of prof. M.A. Maslin to the investigation of fundamental problems of the history of Russian philosophy. An important result of his scientific activity is the book "The diversity and unity of Russian philosophy" (2017) presenting the original authorial approaches to the development of complex problems of the historiography of the Russian philosophical tradition of the $18^{\text {th }}-$ $19^{\text {th }}$ centuries. The history of life and work of Russian thinkers of different epochs and directions forms, according to the author's opinion, a complex polyphonic dialogue of ideas of a single circle of "persons" who in the era of modernity determined the main directions of Russian thought. Particular attention is paid to the profound analysis of prof. M.A. Maslin of the main directions of the evolution of Russian liberal philosophy and political thought, political and sociological aspects of M.M. Bakhtin's creative thinking, as well as very specific problems associated with the various stages in the formation of anthropological, philosophical and socio-political concepts of Russian Eurasianism and its predecessors (for example, "protoeurasianism" of V.I. Lamansky and K.N. Leontiev). The article also emphasizes the consonance of innovative scientific elaborations of M.A. Maslin to the theoretical searches of the largest representatives of foreign schools analyzing the Russian philosophical tradition (A. Walicki), as well as various trends in Western cultural studies (E. Auerbach) and political theory (Ch. Merriam).

Keywords: Professor M.A. Maslin, Russian philosophy, historiography, liberalism, Russian Eurasianism, liberal tradition, culturology, sociological analysis.

Gutorov, Vladimir - D. Sc. in Philosophy, Professor, Head of Department of Theory and Philosophy of Politics, Faculty of Political Science, Saint Petersburg State University.

gut-50@mail.ru 
Shirinyants, Aleksandr - D.Sc. in Political Sciences, Professor, Head of the Department of History of Social and Political Doctrines at the Faculty of Political Science, Lomonosov Moscow State University.

jants@yandex.ru

Citation: GUTOROV V.A., SHIRINYANTS A.A. (2018) The Unity in Diversity or the Versicoloured Faces of Professor M.A. Maslin. (In Connection with the Publication of the Book: Maslin M.A. Diversity and the Unity of Russian Philosophy. Saint Petersburg, Russian Christian Humanities Academy Publ., 2017. - 526 pp.) In: Philosophical Sciences. 2018. Vol. 2, pp. 107-119. DOI: 10.30727/0235-1188-2018-2-107-119.

\section{REFERENCES}

Gutorov V. (ed.) (2015) F. Roosevelt: Pro et Contra. Anthology. Images of the Allied Victors in the Cultural Memory of the War of 1941-1945. Publishing House of the Russian Christian Humanitarian Academy, Saint Petersburg (in Russian).

Gutorov V. (ed.) (2016) Lenin: Pro et Contra. Anthology. Publishing House of the Russian Christian Humanitarian Academy, Saint Petersburg (in Russian).

Gutorov V., Svetlov R. (ed.) (2016) Liberalism: Pro et Contra. Anthology. Publishing House of the Russian Christian Humanitarian Academy, Saint Petersburg (in Russian).

Maslin M.A. (2013) Eurasianism as an Ideological Current: Origins and Borders In: A.G. Kovalenko, V.A. Tsvyk (eds.). Lev Nikolaevich Gumilev and Contemporary Eurasianism: Collection of Articles Dedicated to the $100^{\text {th }}$ Anniversary of the Scientist. Publications of the Russian University of Friendship of Peoples, Moscow, pp. 11-25 (in Russian).

Maslin M.A. (2017) Diversity and Unity of the Russian Philosophy. Publishing House of the Russian Christian Humanitarian Academy, Saint Petersburg (in Russian).

Maslin M., ed. (2007) Russian Philosophy. Encyclopedia. Algorithm, Moscow (in Russian).

Maslin M., ed. (2014) Russian Philosophy. Encyclopedia. 2-nd Edition, Revised and Supplemented. Knigovek, Moscow (in Russian).

Minakov A., Perevezencev S., Shirinyants A., eds. (2016) Guardians of Russia. Anthology. Vol. 3. The Birth of Russian Conservatism. 1800-1850. Publis, Moscow (in Russian).

Perevezencev S.V. (2016) On the Question of the National Character of the Russian Socio-political Thought of the $18^{\text {th }}$ Century In: The Bulletin of the Russian Nation. 2016. Vol. 49. No 3-4, pp. 167-178 (in Russian)

Shirinyants A.A. (2002) Outside of Power and the People. The Political Culture of the Intelligentsia of Russia in the $19^{\text {th }}$ and Early $20^{\text {th }}$ Centuries. The Russian Political Encyclopedia, Moscow (in Russian).

Shirinyants A.A. (2011) Nihilism or Conservatism? (Russian Intelligentsia in the History of Politics and Thought). Publishing House of Moscow University, Moscow (in Russian).

Walicki A. (2015) The Flow of Ideas. Russian Thought from the Enlightenment to the Religious-Philosophical Renaissance. Peter Lang, Frankfurt am Mein. 